\title{
Study of effect of functional ingredients on sensory attributes of ready-to-use (RTU) and ready-to-reconstitute (RTR) health beverages for diabetic population
}

\author{
Poornima ${ }^{1}$ 凶, D. B. Puranik ${ }^{2}$, and Sain M. ${ }^{3}$
}

Received: 28.03.2021

Revised: 27.04.2021

Accepted: 15.05.2021

\begin{abstract}
The current investigation was undertaken to develop Ready to Use (RTU) and Ready to Reconstitute (RTR) health beverage supplemented with functional ingredients. It was developed using double toned milk and replacing part of double toned milk with whey at $20,30 \& 40 \%$, the addition of Stevia:sugar blend (25:75, 50:50 \& 100:00), the addition of almond oil or walnut oil at $2,3 \& 4 \%$ and tea decoction at $10,15 \& 20 \%$ later subjected to sensory evaluation. Finally, based on sensory scores, replacement of double toned milk with $30 \%$ whey, addition 100:0 Stevia:sugar blend, $2 \%$ almond oil or walnut oil and $15 \%$ tea decoction was optimised. The optimised health beverage was concentrated to $31 \%$ total solids and spray dried (inlet $180 \pm 10$ and outlet $80 \pm 10{ }^{\circ} \mathrm{C}$ temperatures) to obtain ready to reconstitute health beverage powder which was packed in plastic pouches and stored at ambient temperature for further studies. The effect of reconstitution on the sensory characteristics was determined for different ratios. Among all ratios, 1:8 reconstituted health beverage was awarded the highest sensory score, which was comparable to control.
\end{abstract}

Key words: Almond oil, Diabetes, Stevia, Tea, Walnut oil, Whey

\section{Introduction}

India is the largest milk-producing country with a yearly outcome of 198.4 million tonnes with a per capita milk availability of around 407 gms per day. About 46 per cent of the total produced milk in the country is consumed as a liquid, and 50-54 per cent of milk is transformed into a number of milk products using various techniques like desiccation, coagulation and fermentation (BAHFS, 2021). In order to maintain good health and overall wellbeing through a cost-effective method is by having good nutrition. People consume various health drink and beverages to meet the basic nutritional requirements and also as a form of hydration. Beverages may be of several types, including water, alcohol, tea, coffee, fruit juices, milk, flavoured milk, lassi or any mixture of these ingredients present in water. Functional beverages are the latest breakthrough in the manufacture and sale of beverages such as ready-to-drink tea and coffee, enhanced dairy, herbal and nutraceutical beverages.

\section{Author's Address}

${ }^{1 \& 3}$ Dairy Engineering Division, ICAR-National Dairy Research Institute, Karnal, Haryana, India- 132001

${ }^{2}$ Department of Dairy Technology, Dairy Science College, Bengaluru, Karnataka, India -560024

E-mail.: poornimapatwadi555@gmail.com
Milk beverages are considered genuine thirstquenching, refreshing, healthy and nutritious product. Whey is a by-product obtained by coagulation of milk by addition of acid and/or rennet or by a change in the Physico-chemical process during the preparation of cheese, paneer, chhana, and/or casein. Many cohort studies have shown that various functionally and physiologically active peptides produced during gastrointestinal digestion positively impact the human body (Gupta et al., 2017). Studies have proved that whey proteins possess antidiabetic, insulinotropic, antioxidant, immunomodulating, antiviral, antimicrobial, anticancer, anti-ulcer activities along with protecting the cardiovascular system which suggests that it can provide functional benefits to heal various diseases. Among all the essential amino acids, Leucine is more important for diabetic subjects due to its chemical structure, which is significantly insulinogenic compared to other essential amino acids as it affects glucose sensing in both, i.e., insulin-dependent and insulinindependent mechanism. The potent glucoregulatory effect of whey proteins and their bioactive peptides directly affects insulin secretion, 


\section{Poornima et al.}

increasing secretion and /or inhibiting dipeptidyl peptidase IV activity (Comeford and Pasin, 2016). Gaudel et al. (2013) experimented on mice and concluded that ingestion of whey proteins and their hydrolysates improved the functioning of pancreatic $\beta$-cells and hence enhanced insulin secretion. Stevenson and Allerton (2017) showed that whey interacts with several mechanisms that affect post-prandial glycaemia, suggesting that whey can lower blood glucose via both mechanisms, i.e., insulin-dependent and insulinindependent. Hence, whey protein acts excellent from both a nutritional and economic point of view. Stevia rebaudiana is a natural sweetest plant that is high in nutrition with zero calories. Stevioside, rebaudioside A-F, steviolbioside etc., are responsible for their sweet taste and is used as a sugar substitute in various cuisines worldwide. Many clinical studies have shown that Stevia possesses multiple beneficial properties such as antidiabetic, antioxidant, antimicrobial and anticancer etc. Stevia leaves contain zero-calorie and taste 300 times sweeter in contrast to sucrose. Besides, Stevia has been shown to be safe, and the Joint FAO/WHO Expert Committee on Food Additives (JEFCA) has established an Acceptable Daily Intake (ADI) of $4 \mathrm{mg} / \mathrm{Kg}$ body weight. Various forms of Stevia are made available in the market, such as dried, powdered or liquid form (Kuntz et al., 2010). Chen et al. (2005) conducted a study on male Wistar rat where they concluded that Stevia enhanced insulin utilisation by regulating the gene expression of phosphoenolpyruvate carboxykinase in rats. So, the excessive intake of sugar has become a significant health concern. Hence there is a fundamental requirement for the replacement of the table sugar with an alternative sweetener. Since Stevia is found to be of natural source with many health benefits, it can be successfully administrated into health beverages.

Almond (Prunus dulcis, syn. Prunus amygdalus) is a tree species local to North Africa, Indian areas and Central East. In ancient times, oil extracted from the almonds was used in ayurvedic treatment for depression, phobias, anxiety, enhancing the immune system, muscle-building power, improving brain functioning, and enhancing cognitive function. $100 \mathrm{~g}$ of almond contains a total of $49 \mathrm{~g}$ of fat in which it has saturated fat $(3.7 \mathrm{~g})$, polyunsaturated fat $(12 \mathrm{~g})$, monounsaturated fat (31 g), calcium (26\%), iron (20\%), magnesium (67\%), carbohydrates $(7 \%)$ and protein $(42 \%)$ (USDA, 2018). According to the American diabetes association (2017), intake of fat, especially polyunsaturated fatty acid (PUFA), along with monounsaturated fatty acid (MUFA), has been liberalised in diabetic diets to increase HDL cholesterol and improve glycaemic control. Almond oil rich has proven to lower post-prandial glycaemia, insulinaemia and oxidative stress in diabetic individuals. Diet rich in MUFA resulted in improved insulin sensitivity and reduced diabetes risk by reducing the serum LDL/HDL ratio and triglycerols (Jenkin et al., 2006, Li et al., 2009 and Riserus et al., 2009).

Walnut (Juglansregia L.) is one of the finest nuts belonging to the Juglandaceae family of the temperate areas. The ripened walnuts are widely eaten like nuts or used in the preparation of desserts, cakes, and confectioneries. On an average, walnut is composed of water $(3.2-4.4 \%)$, protein (12.0- 19.6\%), fat (61.3 - 73.8\%), sugars (2.2 - 4.5 $\%)$ and ash (1.8 - $2.3 \%$ ) (Gecgel et al., 2017). In addition, walnut contains a high number of polyphenols such as ferulic acid, vanillic acid, coumaric acid, myricetin, syringic acid and juglone, iron $(16 \%)$, vitamin B6 (25\%), magnesium (39\%) and vitamin C (2\%). In addition to this, $100 \mathrm{gms}$ of walnut contains around $6.5 \mathrm{~g}$ - saturated fat, $47 \mathrm{~g}$ polyunsaturated fat and $9 \mathrm{~g}$ - monounsaturated fat (Linda et al., 2004), which may help to maintain blood cholesterol level in diabetic patients. Zibaeenezhad et al. (2017) suggested that consuming around $15 \mathrm{ml} /$ day walnut oil for 90 days by type 2 hyperlipidemic diabetic subjects showed a significant decrease in total blood cholesterol levels to $207.7 \pm 39.7$ from $234.1 \pm 33 \mathrm{mg} \mathrm{dl}^{-1}$ along with improvements in blood glucose level. Furthermore, $56 \mathrm{~g}$ of walnut consumption per day for eight weeks improved endothelial function, resulting in reduced serum total cholesterol. Since walnut oil is rich in polyunsaturated fatty acids, it has also been associated with enhancing lipid profile, leading to attenuated cardio-metabolic risks and better glucose tolerance (Ma et al., 2010 and Coelho et al., 2016). Hence, can be used in developing beverages for diabetic people.

Tea (Camellia sinensis) is a perennial acidophilic crop that is also known as a non-alcoholic, aromatic and stimulating beverage that is generally prepared 
by using boiling water or milk and pouring over cured leaves of the Camellia sinensis, which is served in both hot and cold forms. Tea is the most broadly devoured beverage in the world after water. The addition of milk to tea decoction was first documented in 1680 by the epistolist Madame de Sevigne. Green tea is primarily consumed in Japan and China, while black tea is mainly consumed in Western countries, India, and various other countries (Brief Guides, 2006 and Wilson and Temple, 2016). Tea is found to be rich in polyphenols, epigallocatechin gallate, Gallic acid, theaflavins etc. which has shown to possess many health beneficial properties. Many cohort studies have shown that consuming tea is associated with lowering the risk of developing diabetes. Drinking at least 3 cups of tea reduces the risk of developing Type 2 diabetes by around 42 per cent (Dieren et al., 2009). Also, drinking tea for an 8-week intervention (608 subjects) has alleviated the lowering of fasting blood insulin level by $1.30 \mathrm{U} / \mathrm{L}$, $95 \%$ CI of $0.36-2.24$ in type 2 diabetic individuals (Li et al., 2016). The antidiabetic property of tea components, especially catechin, chlorogenic acid, caffeine, and theaflavins, inhibits enzyme activity, especially $\alpha$-glucosidase and $\alpha$-amylase, thereby reducing the absorption and digestion of starch

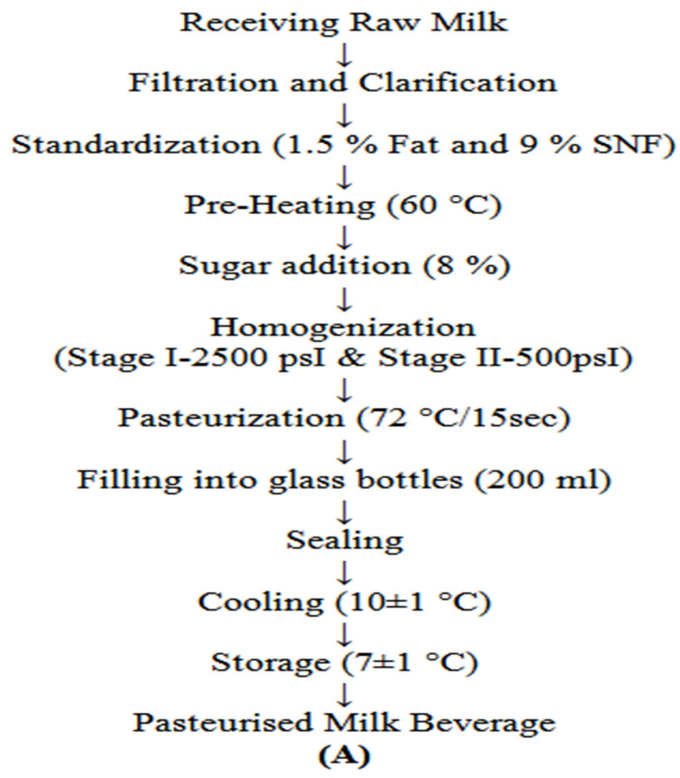

which in turn decreased the blood glucose plasma levels, albuminuria and lipid metabolites. The presence of catechin in tea improves endothelial functioning by activating PI3K signal cells, endothelial nitric oxide synthase (eNOS) enzyme and formation of Nitric oxide (Liu et al., 2016). Furthermore, Mahmoud et al. (2016) have observed that tea and tea extracts provide protective effects against cytokine-induced cell injuries to insulinproducing cells.

\section{Materials and Methods}

Fresh raw milk was collected from Students Experimental Dairy Plant (SEDP), Dairy Science College, Hebbal, Bengaluru, which was subjected to cream separation using the cream separator. Here, skim milk powder and cream were used for standardisation during the preparation of double toned milk containing $1.5 \%$ of Fat and $9 \%$ of Solids Not Fats (SNF), and this was further used in preparing RTU health beverage. Cheddar cheese whey was prepared by using a method (Fig. 1-A) prescribed by Singh (2006). Good quality cane sugar, Stevia (1gm Stevia equivalent to 2 teaspoons of sugar), almond oil, walnut oil and tea powder was procured from the local market.

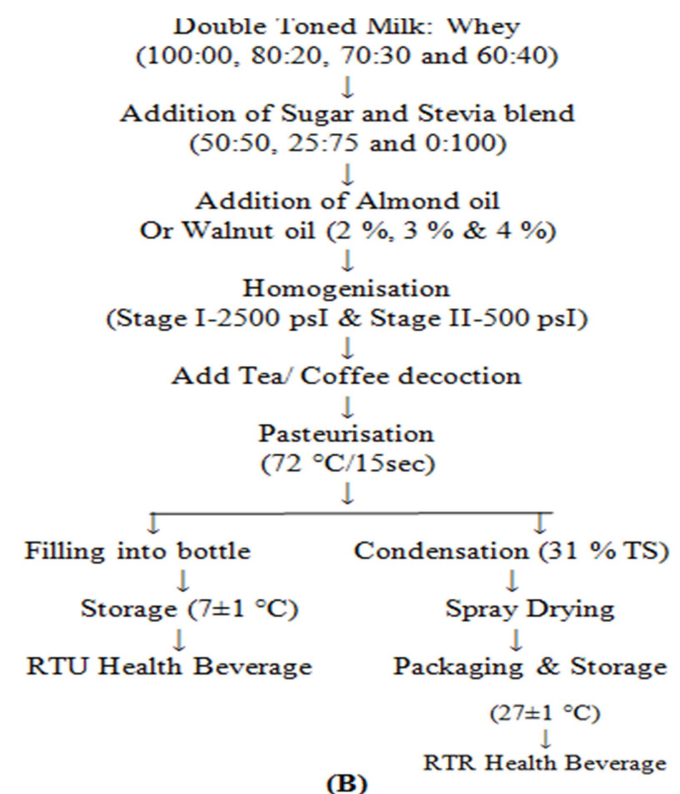

Figure 1: Method adopted for the preparation of control beverage (A) (Singh, 2006) and RTU and RTR Health Beverage (B) 
Preparation of ready to use (RTU) Health Beverage The control beverage was prepared as per the standard protocol using $8 \%$ sugar (on milk total volume basis) (Singh, 2006) and pasteurised at 72 ${ }^{\circ} \mathrm{C} / 15 \mathrm{sec}$ and bottled. The RTU health beverage was prepared by replacing part of the milk with whey $(20,30$ and $40 \%)$ and incorporation of sugar: Stevia $(50: 50,25: 75 \& 00: 100)$, almond oil or walnut oil $(2,3 \& 4 \%)$ and tea decoction $(15,20 \&$ $25 \%$ ).

Preparation of ready to reconstitute (RTR) Health Beverage The developed health beverage was first pasteurised $\left(72{ }^{\circ} \mathrm{C} / 15 \mathrm{sec}\right)$ and then subjected to condensation up to $32 \%$ total solids concentration. Then, the condensed health beverage was spray dried at an inlet temperature of $180 \pm 10$ ${ }^{\circ} \mathrm{C}$ and outlet temperature of $80 \pm 10{ }^{\circ} \mathrm{C}$ with an air pressure of 1.4 bar and vacuum maintained at 570 $\mathrm{mmHg}$. The final product obtained was packed in plastic pouches (Fig. 1-B) and stored at room temperature for further studies.

Sensory evaluation: The RTU and RTR health beverage developed were ranked using a 9-point hedonic scale method of sensory evaluation for its sensory attributes that are colour and appearance, body and texture, flavour, and overall acceptability to a group of trained individuals. The final scores provided by expert panellist were then statistically analysed.

Statistical analysis: The results obtained were an average of three replications, and the design of the experiment were statistically analysed using $\mathrm{R}$ Programme, R-Version, Ri386 3.4.3 for accurate interpretation that helped in discussion (Zar, 2003).

\section{Results and Discussion}

Effect of different levels of whey on the sensory characteristics of health beverage

Different blends of double toned milk and cheddar cheese whey were tried, i.e., 80:20, 70:30 and 60:40 to know the acceptability of product against the control beverage (100:00). The resultant health beverage and control sample was served to a number of panellists for adjudging the sensory attributes and overall acceptability. The highest sensory score was given to $30 \%$ whey replacement compared to that of other levels. The mean sensory score of this blend for colour \& appearance, body and texture, flavour and overall acceptability were
$8.05,8.15,8.20$ and 8.25 (significance, $P=.05$ ), respectively. Hence, $30 \%$ replacement of double toned milk with whey or 70:30 blend of double toned milk and whey was optimised (Table 1). These findings were in support with the results reported by Yadav et al. (2016), where they observed that the addition of soya milk and whey in equal proportion with $8 \%$ sugar was awarded the highest sensory score, i.e., 7.50, 7.33, 7.16 and 7.33 for colour and appearance, mouthfeel, flavour \& overall acceptability, respectively.

Effect of different levels of Stevia on the sensory characteristics of health beverage

Sugar and Stevia blend was added in the ratio of 100:0 (control), 50:50, 25:75 and 0:100 to ready to use health beverage. The subsequent health beverage obtained after adding sugar and Stevia blend and control sample was subjected to sensory evaluation by expert panellists for its sensory attributes. Based on sensory evaluation, a health beverage with 0:100 blend of sugar and Stevia was found optimum. The mean sensory scores of 0:100 blend of sugar and Stevia for colour and appearance, body and texture, flavour and overall acceptability were $8.00,8.06,8.12 \& 8.00$, respectively. Hence, 00:100 blend (sugar: Stevia) was selected and used for further studies, which differed significantly with $P=.05$ and was ranked best amongst all the other blends (Table 2). These findings were supported by Tadhani and Subhash (2009), where replacing sucrose with Stevia, i.e., 50 $\%$ in tea and $75 \%$ in coffee beverage, was acceptable.

Effect of different levels of Almond oil on the sensory characteristics of health beverage Almond oil was added at the rate of $2 \%, 3 \%$ and 4 $\%$. The health beverage with $2 \%$ almond oil scored highest among the other levels compared to control. It was observed that with an increase in the level of almond oil, the scores for all the sensory attributes were decreasing. The mean sensory scored for $2 \%$ almond oil added health beverage were 7.94, 8.20, 8.13 and 8.35 for colour and appearance, body and texture, flavour and overall acceptability. Hence, a health beverage incorporated with $2 \%$ almond oil was selected and used for further studies with significant difference $(P=.05)$ and rated best amongst all blends that were tried (Table 3 ). 
Study of effect of functional ingredients on sensory attributes

Table 1: Effect of different levels of whey on the sensory characteristics of health beverage

\begin{tabular}{|c|c|c|c|c|}
\hline $\begin{array}{c}\text { Levels of whey replacement } \\
(\%)\end{array}$ & Colour and Appearance & Body and Texture & Flavour & Overall Acceptability \\
\hline Control & $8.27^{\mathrm{a}}$ & $8.22^{\mathrm{a}}$ & $8.30^{\mathrm{a}}$ & $8.38^{\mathrm{a}}$ \\
\hline 20 & $7.72^{\mathrm{b}}$ & $7.85^{\mathrm{b}}$ & $7.51^{\mathrm{a}}$ & $7.70^{\mathrm{b}}$ \\
\hline 30 & $8.50^{\mathrm{ab}}$ & $8.15^{\mathrm{a}}$ & $8.20^{\mathrm{ab}}$ & $8.25^{\mathrm{a}}$ \\
\hline 40 & $6.50^{\mathrm{c}}$ & $6.36^{\mathrm{c}}$ & $6.55^{\mathrm{c}}$ & $6.75^{\mathrm{c}}$ \\
\hline $\mathrm{CD}(P=.05)$ & 0.22 & 0.25 & 0.25 & 0.25 \\
\hline
\end{tabular}

(Note: All values are average of three trials, Superscripts $a, b \& c$ indicate significant difference at the corresponding critical difference, Control - Double Toned Milk with $8 \%$ sugar)

Table 2: Effect of different levels of Stevia on the sensory characteristics of health beverage

\begin{tabular}{|c|c|c|c|c|}
\hline Combination of sugar and Stevia & $\begin{array}{l}\text { Colour and } \\
\text { Appearance }\end{array}$ & $\begin{array}{c}\text { Body and } \\
\text { Texture }\end{array}$ & Flavour & $\begin{array}{c}\text { Overall } \\
\text { Acceptability }\end{array}$ \\
\hline Control & 8.05 & $8.15^{\mathrm{a}}$ & $8.20^{\mathrm{a}}$ & $8.25^{\mathrm{a}}$ \\
\hline $50: 50$ & 7.25 & $7.45^{b}$ & $7.40^{\mathrm{ab}}$ & $7.43^{b}$ \\
\hline $25: 75$ & 7.56 & $7.75^{\mathrm{ab}}$ & $7.65^{\mathrm{ab}}$ & $7.75^{b}$ \\
\hline $0: 100$ & 8.00 & $8.06^{\mathrm{ab}}$ & $8.12^{\mathrm{a}}$ & $8.00^{\mathrm{a}}$ \\
\hline $\mathrm{CD}(P=.05)$ & 0.35 & 0.28 & 0.29 & 0.33 \\
\hline
\end{tabular}

(Note: All values are average of three trials, Superscripts $a, b \& c$ indicate significance difference at the corresponding critical difference, Control - $30 \%$ whey added health beverage, the sweetness intensity of Stevia is 10 times more than sugar, and an equivalent quantity of Stevia was added)

Table 3: Effect of different levels of almond oil on the sensory characteristics of health beverage

\begin{tabular}{|c|c|c|c|c|}
\hline Levels of Almond oil (\%) & $\begin{array}{l}\text { Colour and } \\
\text { Appearance }\end{array}$ & Body and Texture & Flavour & $\begin{array}{l}\text { Overall } \\
\text { Acceptability }\end{array}$ \\
\hline Control & 8.05 & $8.15^{\mathrm{a}}$ & $8.00^{\mathrm{a}}$ & $8.25^{\mathrm{a}}$ \\
\hline 2 & 7.94 & $8.20^{\mathrm{a}}$ & $8.13^{\mathrm{a}}$ & $8.35^{\mathrm{a}}$ \\
\hline 3 & 7.38 & $7.50^{\mathrm{b}}$ & $7.67^{\mathrm{b}}$ & $7.68^{\mathrm{b}}$ \\
\hline 4 & 7.08 & $7.32^{\mathrm{b}}$ & $7.56^{\mathrm{b}}$ & $7.41^{\mathrm{b}}$ \\
\hline CD $(P=.05)$ & 0.45 & 0.44 & 0.31 & 0.37 \\
\hline
\end{tabular}

(Note: All values are average of three trials, Superscripts $a, b \& c$ indicate significant difference at the corresponding critical difference, Control $-30 \%$ whey replaced, 0:100 sugar: Stevia added health beverage)

Table 4: Effect of different levels of walnut oil on the sensory characteristics of health beverage

\begin{tabular}{|c|c|c|c|c|}
\hline Levels of Walnut oil (\%) & Colour and Appearance & Body and Texture & Flavour & Overall Acceptability \\
\hline Control & $8.05^{\mathrm{a}}$ & $8.15^{\mathrm{a}}$ & $8.00^{\mathrm{a}}$ & $8.25^{\mathrm{a}}$ \\
\hline 2 & $8.31^{\mathrm{a}}$ & $8.21^{\mathrm{a}}$ & $8.18^{\mathrm{a}}$ & $8.40^{\mathrm{a}}$ \\
\hline 3 & $7.50^{\mathrm{b}}$ & $7.87^{\mathrm{b}}$ & $7.43^{\mathrm{ab}}$ & $7.68^{\mathrm{bc}}$ \\
\hline 4 & $7.43^{\mathrm{b}}$ & $7.56^{\mathrm{b}}$ & $7.25^{\mathrm{b}}$ & $7.62^{\mathrm{c}}$ \\
\hline CD $(P=.05)$ & 0.24 & 0.33 & 0.31 & 0.26 \\
\hline
\end{tabular}

(Note: All values are average of three trials, Superscripts $a, b \& c$ indicate significant difference at the corresponding critical difference, Control - $30 \%$ whey, 0:100 sugar and stevia ratio added health beverage)

Table 5: Effect of different levels of Tea decoction on the sensory characteristics of healthy beverage

\begin{tabular}{|c|c|c|c|c|}
\hline Levels of Tea Decoction \% & $\begin{array}{c}\text { Colour and } \\
\text { Appearance }\end{array}$ & $\begin{array}{c}\text { Body and } \\
\text { Texture }\end{array}$ & $\begin{array}{c}\text { Flavour } \\
\text { Overall Acceptability }\end{array}$ \\
\hline Control & $8.37^{\mathrm{a}}$ & $8.43^{\mathrm{a}}$ & $8.30^{\mathrm{ab}}$ & $8.25^{\mathrm{a}}$ \\
\hline $15(85: 15)$ & $8.31^{\mathrm{a}}$ & $8.12^{\mathrm{a}}$ & $8.28^{\mathrm{a}}$ & $8.20^{\mathrm{a}}$ \\
\hline $20(80: 20)$ & $7.68^{\mathrm{b}}$ & $7.81^{\mathrm{ab}}$ & $7.71^{\mathrm{b}}$ & $7.25^{\mathrm{b}}$ \\
\hline $\mathrm{CD}(75: 25)$ & $7.53^{\mathrm{b}}$ & $7.31^{\mathrm{b}}$ & $7.50^{\mathrm{b}}$ & $7.18^{\mathrm{b}}$ \\
\hline
\end{tabular}

(Note: All values are average of three trials, Superscripts $a, b \& c$ indicate significant difference at the corresponding critical difference, Control - Health beverage replaced with $10 \%(90: 10)$ tea decoction) 
Poornima et al.

Table 6: Effect of reconstitution on the sensory attributes of RTR health beverage

\begin{tabular}{|c|c|c|c|c|}
\hline Level of Reconstitution & $\begin{array}{c}\text { Colour and } \\
\text { Appearance }\end{array}$ & $\begin{array}{c}\text { Body and } \\
\text { Texture }\end{array}$ & Flavour & $\begin{array}{c}\text { Overall } \\
\text { Acceptability }\end{array}$ \\
\hline Control & $8.37^{\mathrm{a}}$ & $8.12^{\mathrm{a}}$ & $8.28^{\mathrm{a}}$ & $8.20^{\mathrm{a}}$ \\
\hline $1: 6$ & $7.40^{\mathrm{b}}$ & $7.50^{\mathrm{b}}$ & $7.30^{\mathrm{b}}$ & $7.40^{\mathrm{b}}$ \\
\hline $1: 8$ & $8.30^{\mathrm{a}}$ & $8.03^{\mathrm{a}}$ & $8.25^{\mathrm{a}}$ & $8.00^{\mathrm{a}}$ \\
\hline $1: 10$ & $7.30^{\mathrm{b}}$ & $7.73^{\mathrm{b}}$ & $7.10^{\mathrm{b}}$ & $7.00^{\mathrm{b}}$ \\
\hline $\mathrm{CD}(P=.05)$ & 0.22 & 0.20 & 0.20 & 0.24 \\
\hline
\end{tabular}

(Note: All values are average of three trials, Superscripts $a, b \& c$ indicate significant difference at the corresponding critical difference, Control -Developed RTU health beverage)

Effect of different levels of walnut oil on the sensory characteristics of health beverage

Walnut oil was added at 2, 3 and $4 \%$ to the healthy beverage. The results pertaining to the effect of different levels of walnut oil on sensory attributes of healthy beverage can be seen in Table 4. Among different levels, $2 \%$ addition was found to be acceptable. Health beverage incorporated with $2 \%$ walnut oil showed a sensory score of $8.31,8.21$, 8.18 and 8.40 for colour and appearance, body and texture, flavour and overall acceptability, respectively. It was seen that the sensory scores were decreasing in trend with an increase in the per cent of walnut oil addition. This may be due to a higher percentage of fat, resulting in a thicker product and higher viscosity, as walnut oil has a tendency to increase the viscosity and undesirable mouthfeel. Health beverage with $2 \%$ addition showed pronounced flavour, which could be due to the better mouthfeel imparted by walnut oil. The addition of a $2 \%$ level of walnut oil was optimised in the experimental health beverage. The kinds of literature supporting this study relevant to a comparison between different oil in milk-based health beverage were found to be scanty.

Effect of different levels of Tea decoction on the sensory characteristics of RTU health beverage The tea decoction was optimised by replacing health beverage with tea decoction at the level of 15 $\%, 20 \%$ and $25 \%$ (Table 5). The highest sensory score was awarded to health beverage containing 15 $\%$ tea decoction compared to other levels. The mean sensory score of health beverage containing $15 \%$ tea decoction were $8.31,8.12,8.28$ and 8.20 with respect to colour and appearance, body and texture, flavour and overall acceptability. It was observed that with an increase in per cent replacement of health beverage with tea decoction, the sensory scores were decreasing. Finally, a health beverage prepared with $15 \%$ replacement with tea decoction was optimised. These findings were found to be superior to tea fortified lassi as reported by Bhang (2012), where the product scored 7.86, 7.40, 7.60 and 7.70 for colour and appearance, mouthfeel, flavour \& overall acceptability, respectively for $10 \%$ extract addition to lassi when concentrated tea extract was added at $5,10,15$ and $20 \%$.

Effect of reconstitution on the sensory attributes of RTR health beverage

The effect of reconstitution of powdered form of RTR health beverage at 1:6, 1:8 and 1:10 ratio were tried. The sensory scores regarding the effect of reconstitution on colour and appearance, body and texture, flavour and overall acceptability is shown in Table 6. Reconstituting at 1:8 ratio was found to be optimum with the highest sensory scores amongst all the other reconstitution ratios. The sensory score at 1:8 ratio obtained in terms of colour and appearance, body and texture, flavour \& overall acceptability were $8.30,8.20,8.28$ and 8.0, respectively. In the case of colour and appearance, 1:6 and 1:10 ratio reconstituted health beverage sample secured the lowest score, and this may be due to change in intensity of colour. With an increase in the rate of reconstitution, i.e. from 1:6 to $1: 10$, the product became dull in colour. Similarly, in the case of body and texture, the lowest scores were awarded to the 1:6 and 1:10 ratio of reconstitution, which could be due to unacceptable product consistency. Hence, with an increase in reconstitution level, the product became thicker and showed higher viscosity. A similar trend was followed in the case of flavour scores. At 1:6 ratios, it had a strong tea flavour, and at 1:10 ratio, it 


\section{Study of effect of functional ingredients on sensory attributes}

showed a flat flavour. This could be a due effect of the reconstitution ratio on the flavour of reconstituted health beverage. It was observed that among different ratio of reconstitution, the 1:8 ratio reconstituted sample was comparable with control health beverage in overall acceptability, which may be because of optimum colour and appearance, pleasant flavour and consistency, which yielded a better product with the highest sensory scores. These scores were similar to the sensory score of reconstituted flavoured milk $(0.5 \%$ cocoa $)$ as reported by Takami et al. (2016), which had a sensory score of $5,3.5$ and 5 out of 5 for colour taste and odour, respectively.

\section{Conclusion}

The investigation was carried out to develop a healthy beverage that would provide overall wellbeing health benefits to diabetic subjects. Also, the sensory attributes was studied during the effect of

\section{References}

ADA, 2017. American diabetes association. Standards of medical care in Diabetes. Diabetes care, 37:14-80.

BAHFS, 2021. Basic Animal Husbandry and Fisheries Statistics, Ministry of Animal Husbandry, Government of India.

Bhang, S. 2012. Development and functional evaluation of tea fortified synbiotic lassi. thesis submitted to dairy technology division, National Dairy Research Institute, Karnal, India, in the partial fulfilment for the requirement for degree of M.Sc.

Brief Guide, 2006. Brief guide to tea. http://www.briefguides. co.uk/content/tea.

Chen, T. S., Chen, S. E., Chan, P., Chu, Y., Yang, H. and Cheng, J. 2005. Mechanism of the hypoglycemic effect of

stevioside, a glycoside of Stevia rebaudiana Plant. Plant Medica, 71:108-113.

Coelho, O. G. L, Silva, D. B. P., Rocha, D. M. U. S. P., Lopes, L. L. and Alfeneas, R. D. 2016. Polyunsaturated fatty acids and type 2 diabetes: impact on the glycemic control mechanism. Critical Reviews in Food Science and Nutrition, 57:3614-3619.

Comerford, K. B. and Pasin, G. 2016. Emerging evidence for the importance of dietary protein source on glucoregulatory markers and type 2 diabetes: different effects of dairy, meat, fish, egg and plant. Nutrients, 8:2-5. different functional ingredients on the development of RTU and RTR health beverage. It revealed that the health beverage prepared using $30 \%$ replacement with whey or 70:30 blend of double toned milk and whey, the addition of 00:100 blend of sugar and Stevia, incorporation of $2 \%$ almond oil or walnut oil, and $15 \%$ of tea decoction was optimised and had many health beneficial properties. The findings of this investigation would be health beneficial or profitable for household consumers and to beverage industries. Developing this healthy beverage at the marketing level would be a promising profit providing a product that would help to improve consumer's overall health in day-to-day life due to the presence of functional ingredients. For diabetic people, this beverage can act as a promising substitute instead of regular milk tea. This product can be consumed on a regular basis for its low-calorie content and healthpromoting constituents.

Dieren, S. V., Uiterwaal, C. S. P. M., Schouw, Y. T.V.D., Der A.D. L. V., Boer, J. M. A., Spijkerman, A., Grobbee, D. E. and Beulens, J. W. J. 2009. Coffee and tea consumption and risk of type 2 diabetes. Diabetologia Springer, 52:2561-2569.

FDA, 2008. Food and drug administration, center for food safety and applied nutrition (CFSAN)/ office of food additives. Agency response letter GRAS notice No. GRN 000252 .

Food and Agriculture Organization, World Health of the United Nations.63. www.fao.org/es/esn/jecfa/index_en.stm

Gaudel, C., Nongonierma, A.B., Maher, S., Flynn, S., Krause, M., Murray, B. A., Kelly, P. M., Baird, A. W., Fitzgerald, R. J. and Newsholme, P. 2013. A whey protein hydrolysate promotes insulinotropic activity in a clonal pancreatic $\beta$ cell line and enhances glycemic function in ob/ob mice. The Journal of Nutrition, 143: 1110-1113.

Gecgel, U., Gumus, T., Tasan, M. and Arici, M. 2017. Determination of fatty acid composition of irradiated hazelnuts, walnuts, almonds, and pistachios. Radiation Physics and Chemistry, 80(4):578-58.

Gupta, M., Yadav, M. P. S., Chauhan, A. S. and Averma, R. 2017. Physico-chemical qualities of papaya pulp based whey beverage. International Journal of Pure Applied Bioscience, 5: 341-45. 


\section{Poornima et al.}

JEFCA 2004. Joint FAO/WHO Expert Committee on Food Additives.

Jenkins, D. J. A., Kendall, C. W. C., Joss, A. R., Salvatore, S., Brighenti, F., Augustin, L. S. A., Ellis, P. R., Vidgen, E. and Rao, V. 2006. Almonds decrease post-prandial glycemia, insulenemia and oxidative damage in healthy individuals. The Journal of Nutrition, 136(12): 29872991.

Kuntz, L. A. 2010. Stevia's sweet story. Food Product Design, $20: 1-6$.

Li, T., Liu, J., Zhang, X. D. and Ji, G. 2015. Antidiabetic activity of lipophilic epigallocatechin-3-gallate derivative under its role of $\alpha$-glucosidase inhibition. Biomedicine Pharmacotherapy, 61(1): 91-6.

Li, T. Y., Brennan, A. M., Wedick, N. M., Mantzoros, C., Nader Rifai, N. and Hu, F. B. 2009. Regular consumption of nuts is associated with a lower risk of cardiovascular disease in women with Type 2 Diabetes. The Journal of Nutrition, 139(7): 1335-1337.

Li, Y., Wang, C., Huai, Q., Guo, F., Liu, L., Feng, R. and Sun, C. 2016. Effects of tea or tea extract on metabolic profiles in patients with type 2 diabetes mellitus: a meta-analysis of ten randomised controlled trials. Diabetes/Metabolism Research and Reviews, 32(1): 2-10.

Linda, C., Tapsell, Lynda, J., Gillen, Craig, S., Patch., Marijka., Batterham., Owen, A., Bare, M. and Kennedy, M. 2004. Including walnuts in a low fat/ modified-fat diet improves HDL cholesterol-to-total cholesterol ratios in patients with type 2 diabetes. American Diabetes Association, 27:2777-2783.

Liu, S. Y., Yu, Z., Zhu, H. K., Zhang, W. and Chen, Y. Q. 2016. In vitro alphaglucosidase inhibitory activity of isolated fractions from water extract of qingzhuan dark tea. BMC Complementary and Alternative Medicine, 16: 37888.

Ma, Y., Njike, V. Y., Millet, J., Dutta, S., Doughty, K., Treu, J. A. and Katz, D. L. 2010. Effect of walnut consumption on endothelial function in type 2 diabetic subjects. Diabetes Care, 33: 227-231.
Mahmoud, F., Haines, D., Al-Ozairi, E. and Dashti, A. 2016. Effect of black tea consumption on intracellular cytokines, regulatory $\mathrm{t}$ cells and metabolic biomarkers in type 2 diabetes patients. Phytotherapy Research, 30(3): 454-462.

Riserus, U., Wilett, W. C. and Hu, F. B. 2009. Dietary fat and prevention of type 2 diabetes. Progress in Lipid Research, 48(1): 44-50.

Singh, S. 2006. Cheese technology. Dairy Technology. New India Publisher Agency, 564-567.

Stevenson, E. J. and Allerton, D. M. 2017. The role of whey protein in post-prandial glycaemic control. Proceedings of the Nutrition Society, 77: 42-51.

Tadhani, M. B. and Subhash, R. 2009. Stevioside and stevia leaf extract as a replacement of sucrose in common beverages: sensory evaluation. Beverage and Food World, 36(1): 55-59.

Takami, Hejazian, S. and Shendi, E. G. 2016. Evaluation of produced flavoured low lactose milk powder for lactose intolerant. Modern Applied Science, 10(1): 149-152.

USDA, 2018. United States Department of Agriculture Agricultural Research Service. Food Composition Databases. https://ndb.nal.usda.gov.

Wilson, T. and Temple, J. N. 2016. Beverage impacts on health and nutrition, 9-50.

Yadav, R., Dhiman, P. and Siwatch, M. 2016. Preparation and analysis of physicochemical and organoleptic properties of soy based beverages. International Journal of Enhanced Research in Science Technology \& Engineering, 5(2): 3133.

Zar, J. H. 2003. Bio statistical analysis. J. H. Pub. Pearson Edu. Pvt. Ltd., New Delhi.

Zibaeenezhad, M. J., Farhadi, P., Attar, A., Mosleh, A., Amirmoezi, F. and Azimi, A. 2017. Effects of walnut oil on lipid profiles in hyperlipidemic type 2 diabetic patients: a randomised, double-blind, placebo-controlled trial Nutrition and Diabetes, 7:1-5. 